\title{
Randomised controlled trial of lymphoblastoid interferon for chronic active hepatitis B
}

\author{
M G ANDERSON, T J HARRISON, G ALEXANDER, A J ZUCKERMAN, \\ AND I M MURRAY-LYON \\ From the Gastrointestinal Unit, Charing Cross Hospital; Liver Unit, Kings College Hospital and \\ Department of Medical Microbiology, London School of Hygiene and Tropical Medicine, London WCI
}

SUMmaRY Thirty male patients ( 27 homosexual) with biopsy proven chronic active hepatitis B were randomised to receive lymphoblastoid interferon (Wellferon) or no treatment. All patients were $\mathrm{HBeAg}$ positive and had continuing viral replication. Patients receiving treatment were given a single daily intramuscular injection of interferon for 28 days at a starting dose of $2.5 \mathrm{MU} / \mathrm{m}^{2}$ increasing to a maximum of $7.5 \mathrm{MU} / \mathrm{m}^{2} / \mathrm{day}$. Transient side effects of malaise and influenza like symptoms occurred in all patients and resolved rapidly after treatment. Hepatitis B viral replication was suppressed during interferon treatment in all patients but the effect was limited to the period of therapy. After one year there was no appreciable difference in viral markers between the two groups of patients and this treatment schedule appears less effective than the thrice weekly, three month regimes recently reported from other centres.

There is considerable interest in the use of antiviral drugs for the treatment of chronic active hepatitis B during the phase of active viral replication. The observation that the hepatic inflammation may subside when viral replication ceases ${ }^{\prime 2}$ has encouraged the trial assessment of a number of antiviral agents. The interferons, a family of glycoproteins, have both widespread immunomodulatory and antiviral effects. Lymphoblastoid interferon (Wellferon), containing at least eight polypeptides, has been shown to have an antiviral effect against hepatitis B (2) and we undertook a randomised controlled trial of this agent versus no treatment for chronic active hepatitis $\mathrm{B}$.

\section{Methods \\ PATIENTS \\ Thirty four consecutive outpatients with documented chronic hepatitis B and satisfying the entry criteria were offered entry to the study and 30 accepted. Their characteristics are shown in the Table. All were \\ Address for correspondence: Dr I Murray-Lyon. Gastrointestinal Unit. Charing Cross Hospital. Fulham. London W6. \\ Received for publication 16 September 1986}

adult men known to have carried the hepatitis $B$ virus (HBV) for more than six months and to be positive in serum for $\mathrm{HBeAg}$. HBV DNA, or its associated polymerase (HBV DNAp), was detected in all patients, (HBV DNAp was present in 27 of 30 patients; HBV DNA was present in all 27 patients tested including the three who were negative for HBV DNAp). All had undergone liver biopsy within six months of entry showing chronic active hepatitis and in six of these patients active cirrhosis was also seen. No patient had received previous antiviral therapy, nor any immunomodulatory agents within the last year. Homosexual and heterosexual men were randomised separately. Treated patients underwent a further liver biopsy one year after entry.

Patients randomised to the treatment group were admitted to hospital for the first three days of treatment and thereafter attended daily for the remainder of the treatment period. They received a single daily intramuscular injection of lymphoblastoid interferon (Wellferon, Wellcome Research Laboratories) for 28 consecutive days. The initial daily dose of $2.5 \mathrm{MU} / \mathrm{m}^{2}$ was increased in increments to a maximum of $7.5 \mathrm{MU} / \mathrm{m}^{2}$ if tolerated. Paracetamol was given as an antipyretic when required. Both 
Table Characteristics of the two patient groups.

\begin{tabular}{|c|c|c|c|c|c|c|c|c|c|c|}
\hline \multirow{2}{*}{\multicolumn{2}{|c|}{$\begin{array}{l}\text { No Age } \\
\text { Treated group }\end{array}$}} & \multirow[t]{2}{*}{$\begin{array}{l}\text { Months } \\
\text { HBs Ag+ } \\
\text { at entry }\end{array}$} & \multirow[t]{2}{*}{$\begin{array}{l}\text { Anti- } \\
\text { DELTA }\end{array}$} & \multirow[t]{2}{*}{$\begin{array}{l}\text { Anti- } \\
\text { HTLV3 }\end{array}$} & \multicolumn{2}{|c|}{$\begin{array}{l}\text { Pretreat } \\
H B V D N A \\
\text { Liver serum }\end{array}$} & \multicolumn{2}{|c|}{$\begin{array}{l}\text { Post-treat } \\
\text { HBV DNA } \\
\text { Liver serum }\end{array}$} & \multirow[t]{2}{*}{$\begin{array}{l}\text { AST on } \\
\text { entry }\end{array}$} & \multirow[t]{2}{*}{$\begin{array}{l}\text { AST on } \\
\text { treat }\end{array}$} \\
\hline & & & & & & & & & & \\
\hline 1 & 33 & 25 & - & + & Frec & + & Frec & + & 110 & $200)$ \\
\hline 2 & 33 & 20 & - & + & NT & + & NT & + & 55 & 80 \\
\hline $3^{*}$ & 27 & 29 & + & - & Frec & + & - & - & 55 & 120 \\
\hline 4 & 34 & 20 & - & + & Frec & + & Frec & + & 23 & 55 \\
\hline 5 & 32 & 62 & - & - & Frec & + & Frec/Int & - & 80 & 86 \\
\hline 6 & 57 & 9 & - & - & Frec & + & NT & + & 180 & 181 \\
\hline 7 & 42 & 50 & - & - & Frec & + & NT & + & 105 & 160 \\
\hline 8 & 37 & 15 & - & - & NT & + & Frec & + & 42 & 60 \\
\hline 9 & 31 & 7 & - & + & NT & + & Frec & + & 37 & 62 \\
\hline 10 & 50 & 32 & - & - & NT & + & Frec & + & 70 & 110 \\
\hline 11 & 22 & 9 & - & - & NT & + & Frec & + & 50 & 78 \\
\hline 12 & 28 & 40 & - & + & NT & + & Frec & + & 70 & 89 \\
\hline 13 & 34 & 7 & - & - & NT & + & Free & + & 780 & 510 \\
\hline 14 & 38 & 20 & NT & NT & NT & NT $\ddagger$ & NT & + & 42 & 56 \\
\hline \multicolumn{11}{|c|}{ Control group } \\
\hline 15 & 25 & 30 & - & - & Frec & + & NT & + & 65 & \\
\hline 16 & 40 & 27 & - & - & Frec & + & NT & + & 80 & \\
\hline 17 & 35 & 12 & - & - & Frec & + & NT & + & 126 & \\
\hline 18 & 32 & 32 & - & - & Frec & + & NT & + & 65 & \\
\hline $19^{*}$ & 30 & 35 & - & - & Frec & + & NT & + & 75 & \\
\hline $20 *$ & 47 & 9 & - & - & Frec & + & NT & + & 50 & \\
\hline 21 & 28 & 33 & - & - & Frec & + & NT & + & 40) & \\
\hline 22 & 41 & 8 & - & - & Frec & + & NT & + & 200 & \\
\hline 23 & 39 & 8 & - & - & Frec & + & NT & + & 70 & \\
\hline 24 & 34 & 19 & + & + & NT & + & NT & + & 98 & \\
\hline 25 & 29 & 14 & - & + & Free & + & NT & + & 50 & \\
\hline 26 & 39 & 42 & - & - & Free & + & NT & + & 49 & \\
\hline $27 \dagger$ & 44 & 7 & NT & NT & Frec & + & \multicolumn{2}{|c|}{ Deccased } & & \\
\hline 28 & 29 & 27 & - & + & Frec & + & NT & + & 42 & \\
\hline 29 & 42 & 14 & NT & NT & NT & NT $\ddagger$ & NT & + & 135 & \\
\hline 30 & 27 & 23 & NT & NT & NT & NT $\ddagger$ & NT & + & 92 & \\
\hline
\end{tabular}

NT $=$ not tested. ${ }^{*}=$ heterosexual, all other patients were homosexual; $\dagger=$ died shortly after entry; $\ddagger=$ these patients were all HBV DNA polymerase positive. Serum aspartate transaminase (AST) measured in Iu/l (normal range $<40$ ). The value of AST shown during treatment is the maximum attained at any time whilst receiving interferon. Post-treatment assessment of HBV DNA in liver and serum was carricd out one year after entry.

groups of patients were seen regularly in outpatients throughout the duration of the study. The protocol for this study was approved by the local ethical committee and all patients gave informed written consent.

During treatment the full blood count, platelet count, urea and electrolytes, bilirubin, total protein, albumin, alkaline phosphatase and serum aminotransferases were measured weekly. The presence of hepatitis B surface antigen ( $\mathrm{HBsAg}$ ) was detected in serum samples by ELISA (Organon Teknica). Antibodies to HBsAg (anti-HBs) and to hepatitis B core antigen (anti-HBc) were detected by radioimmunoassay ('AUSAB' and 'CORAB', Abbott Laboratories). The presence of $\mathrm{HBeAg}$ and anti-HBe were determined by ELISA. Hepatitis B virus associated DNA polymerase activity (HBV DNAp) was assayed using $3 \mathrm{H}$ thymidine incorporation as previously described. Where sufficient liver tissue was obtained a portion of the biopsy was snap frozen in liquid nitrogen and later analysed for the presence of free and/or integrated HBV DNA. ${ }^{+}$The presence of HBV DNA in serum was detected using a non-quantitative dot hybridisation method. S Stored sera obtained at entry to the study and one year later was also tested by radioimmunoassay for the presence of antibody to human T cell lymphotropic virus type 3 (anti-HTLV3)** and by radioimmunoassay for antibody to the delta agent (IgG anti-delta).

\section{Results}

Fourteen patients were randomised to the treatment group and 16 to the control group; 28 patients completed the study. One patient in the treatment group was withdrawn after four days when his liver

"Since the submission of this paper the international nomenclature for IITV 3.3 has been changed to HIV. 
function tests showed that immediately before treatment he had developed an anicteric non- $A$ non-B hepatitis and treatment was stopped in patient 10 after three weeks when he developed a diarrhoeal illness associated with the isolation of Salmonella sp from his stools. One patient in the control group died from gastrointestinal haemorrhage within six weeks of entry.

The two groups were similar in relation to age and known duration of HBV carriage. Twenty seven patients were homosexual. Two homosexual patients were from Mediterranean countries and the remaining 28 patients were all caucasian and born in Great Britain.

One patient in each group was positive in serum for antibody to the delta agent. A total of eight patients, five treated and three controls, were positive for antiHTLV 3 at both entry and exit from the study. No patient became anti-HTLV3 positive within one year of entry into the study. Among the anti-HTLV3 positive patients, one treated patient developed persistent generalised lymphadenopathy three months after entry, two control patients developed persistent generalised lymphadenopathy during the study and one treated patient developed the acquired immunodeficiency syndrome nearly three years after entry to the study.

The side effects of interferon treatment were mainly malaise, which reversed rapidly after the completion of therapy, and influenza like symptoms to which tolerance developed despite the continuation of therapy. These systemic effects were most marked in older patients. Reversible myelosuppression was seen in several patients and where the granulocyte count fell below $1 \times 10^{\circ} / 1$ the dose of interferon was reduced or treatment stopped until the granulocyte count exceeded this figure. Using this treatment regime almost all patients were readily able to tolerate a daily dose of $5 \mathrm{MU} / \mathrm{m}^{2}$ but greater dosages were likely to lead to an eventual interruption in therapy.

During interferon treatment, viral replication as measured by HBV DNA polymerase was reduced in all patients and became transiently negative in seven patients at some stage during their treatment. There was, however, no apparent long term effect on viral replication. In two treated patients HBV DNA and HBV DNAp became negative during follow up and both developed anti-HBe, five and 18 months respectively after treatment. One untreated patient also lost HBV DNA and HBV DNAp but was still $\mathrm{HBeAg}$ positive 12 months after entry to the study when he was lost to follow up.

Twelve of the treated patients underwent repeat liver biopsy one year after entry. In patient 14 the latter biopsy was classified as chronic persistent hepatitis while in the remaining patients the histological findings were similar, or the inflammatory infiltrate was more marked, than at entry to the study.

In two of the treated patients qualitative changes were observed in the post-treatment liver biopsies by nucleic acid hybridisation studies using an HBV genomic probe. In one patient, no HBV DNA sequences could be observed in the hepatocytes in a post-treatment biopsy which was taken immediately before seroconversion to anti-HBe. In the second, integrated HBV DNA sequences, as well as replicating viral DNA were detected in the post-treatment biopsy, where only replicative forms had been detected pretreatment. This patient also seroconverted to anti-HBe shortly after the second biopsy was carried out. In both these patients, examination of the pretreatment biopsies revealed very low levels of viral replication and we cannot determine whether their seroconversion was attributable to interferon treatment or the natural progression of their disease. Interestingly, in the control group, where no anti$\mathrm{HBe}$ seroconversions occurred, all pretreatment biopsies examined had relatively high levels of replicating HBV DNA.

\section{Discussion}

Initial studies of interferon in chronic hepatitis B were hampered by limited availability of the drug. IFN-B appeared relatively ineffective ${ }^{\prime}$ and although IFN-A was shown to have a transient effect on HBV DNA polymerase ${ }^{7}$ there was no apparent benefit over a longer period. ${ }^{*}$ Higher dosages of IFN-A, given alone or in combination with adenine arabinoside, produced long term suppression of viral replication" with loss of infectivity in a proportion of patients" but these studies were uncontrolled. Another uncontrolled study, from Japan and using low doses of IFN-A, produced an apparently high rate of response."

Since the start of our study, thrice weekly rather than daily lymphoblastoid interferon has been shown to be effective in inhibiting hepatitis $\mathrm{B}$ virus replication $^{12}$ and appears to be more effective when given in three month courses. ' Recombinant IFN-A has also been shown to suppress viral replication ${ }^{13}$ and courses longer than those used in our study were again more effective. ${ }^{14}$ These different responses to treatment may reflect differences in interferon dosages and duration of treatment as well as variation in the rate of spontaneous cessation of viral replication and seroconversion to anti-HBe positivity seen in different groups of chronic hepatitis B carriers. ${ }^{15}$ Male homosexuals, who are likely to form the largest group of chronic hepatitis B carriers in Western 
countries suitable for antiviral treatment, may show altered immune responsiveness ${ }^{\text {th }}$ and also appear to respond less well to treatment. ${ }^{17}$

Interferons may have immunosuppressive effects when given in high dosage and this may be important if viral clearance of $\mathrm{HBV}$ depends on the alterations to the immune system as well as the direct antiviral effects. The dosages in this study were immunosuppressive as shown by the effects on natural killer (NK) cell activity (unpublished observations). Studies using different dosage regimes are currently in progress and may help to clarify the relative importance of the immunomodulatory and antiviral effects of the interferons in chronic HBV.

At the time of this study HTLV3 infection was already present amongst the male homosexual population in London and the prior exposure to this agent in eight of our study patients might have been expected to alter their response to treatment.' We found no obvious difference, however, in response between anti-HTLV3 positive and negative patients. In future controlled studies in different ethnic groups, allowing both for homosexuality and HTLV3 status, will be required to assess the efficacy of the various interferons.

Toxicity of lymphoblastoid interferon was not a major problem during this study and the side effects were both predictable and reversible. These unwanted effects appear to be less pronounced using an intermittent regime which preserves the antiviral efficacy. During this study patients attended daily for treatment with considerable interruption of their daily lives. During subsequent studies we have found that almost all patients can be taught to give their own injections subcutaneously and absorption from this route appears to be equally effective.

This study shows that a one month course of lymphoblastoid interferon appears to have no long term benefit on chronic hepatitis B virus replication, but longer courses of this agent given thrice weekly are showing promise.

We are grateful to Dr B Evans and the department of genitourinary medicine for referring many of the patients and to $\mathrm{Dr} \mathrm{R}$ Williams for permission to include some of the patients under his care. Dr $\mathbf{J}$ Coleman and $\mathrm{Mr} \mathrm{R}$ Dayton provided valuable assistance with virological assays. MGA was supported by the Bernard Sunley Charitable Foundation. Wellcome Research Laboratories supplied the Wellferon and provided financial support towards the study. Results from this study were presented in part at an international meeting on the treatment of chronic hepatitis B held at the Royal Society, London, in October 1985.

\section{References}

1 Thomas HC, Scully LJ. Antiviral therapy in hepatitis B infection. Br Med Bull 1985; 41: 374-80).

2 Sherlock S, Thomas HC. Treatment of chronic hepatitis due to hepatitis B virus. Lancet 1985; ii: 1343-6.

3 Fang CT, Nath N, Pielech M, Dodd RY. A modified technique for the detection of hepatitis $B$ virus specific DNA polymerase. J Virol Methods 1980; 2:349-56.

4 Harrison TI, Anderson MG, Murray-Lyon IM, Zuckerman AJ. Hepatitis B virus DNA in the hepatocyte - a series of 160) biopsies. J Hepatol 1986; 2: 1-10.

5 Harrison TJ, Bal V, Wheeler EG, Meacock TJ, Harrison JF, Zuckerman AJ. Hepatitis B virus DNA and e antigen in the sera of HBsAg-positive UK blood donors. $\mathrm{Br}$ Med $J$ 1985; 290: 663-4.

6 Kingham JGC, Ganguly NK, Shaari ZD, et al. Treatment of HBsAg positive chronic active hepatitis with human fibroblast interferon. Gut 1978; 19: 91-4.

7 Greenberg HB, Pollard RB, Lutwick LI, Gregory PB, Robinson WS, Merigan TC. Effect of leukocyte interferon on hepatitis B virus infection in patients with chronic active hepatitis. N Engl J Med 1976; 295: 51722.

8 Schalm SW, Heijtink RA. Spontaneous disappearance of viral replication and liver cell inflammation in HBsAg-positive chronic active hepatitis: results of a placebo vs. interferon trial. Hepatology 1982; 2: 791-4.

9 Scullard GH, Pollard RB, Smith JL, et al. Antiviral treatment of chronic hepatitis $B$ virus infection. 1. Changes in viral markers with interferon combined with adenine arabinoside. $J$ Infect Dis 1981 ; 143: 772-83.

10 Scullard GH, Greenberg HB, Smith JL, Gregory PB, Merigan TC, Robinson WS. Antiviral treatment of chronic hepatitis B virus infection: infectious virus cannot be detected in patient serum after permanent responses to treatment. Hepatology 1982; 2: 39-49.

11 Matsumura N, Yoshikawa T, Kondo M, Kawakami H, Kishida T. Therapeutic effect of a low dosage of human leukocyte interferon on chronic hepatitis B virus infection. Digestion 1983; 26: 205-12.

12 Lok ASF, Weller IVD, Karayannis P, et al. Thrice weekly lymphoblastoid interferon is effective in inhibiting hepatitis B virus replication. Liver 1984; 4: 4.5-9.

13 Smith CI, Weissberg J, Bernhardt L, Gregory PB, Robinson WS, Merigan TC. Acute Dane particle suppression with recombinant leukocyte $A$ interferon in chronic hepatitis B virus infection. J Infect Dis 1983; 148: 907-13.

14 Dusheiko G, Dibisceglie A, Bowyer S, et al. Recombinant leukocyte interferon treatment of chronic hepatitis B. Hepatology 1985; 5: 556-60.

15 Anderson MG, Murray-Lyon IM. Natural history of the HBsAg carrier. Gut 1985; 26: 848-60.

16 Anderson MG, Eddlestone ALWF, Murray-Lyon IM. Altered natural history of hepatitis $\mathrm{B}$ in homosexual males - a reflection of altered immune responsiveness? $J$ Med Virol 1985; 17: 167-73.

17 Novick DM, Lok ASF, Thomas HC. Diminished responsiveness of homosexual men to antiviral therapy for HBsAg positive chronic liver disease. J Hepatol 1985; 1 : 29-35. 